早稲田大学 スポーツ科学学術院 准教授 皆苏架織

\title{
【略 歴】
}

早稲田大学スポーツ科学学術院准教授。博士 (医学)。専門は健康教育学、発育発達学。東京医科大 学大学院公衆衛生学講座修了。現所属助手、助教を経て現職。主に子どもから高齢者までの健康増 進を目的とした身体活動を推進するための研究に従事。 


\section{望ましい身体活動へ変容するための新しいアプローチ}

身体活動や運動不足が、心疾患、脳卒中、糖尿病、がんなどの非感染性慢性疾患 (Noncommunicable disease；NCD）による死亡原因の第 4 位となっており、全世界で毎年300万人以上の予防できるはずの 命が奪われている。身体活動不足は、日本を含む先進国において年々増加している。日本では、1 回 30分以上の運動を週 2 回以上実施し、1 年以上継続している者の割合は、男性で $35.9 \%$ 、女性で $28.6 \%$ であり、この10年間ほぼ横ばいである（平成29年国民健康・栄養調査）。そのため、身体活動を推進す ることは、公衆衛生上喫緊の課題である。

わが国では、特定健診・保健指導にて身体活動や運動習慣の改善が取り組まれている。しかし、国 の調查結果を見ても、身体活動や運動習慣の改善は認められない。保健指導の対象となる者は、そも そも身体活動・運動量が少なく、体を動かすことが嫌いであったり、抵抗感を持っている者が多い。 本シンポジウムでは、従来の「運動しましょう!」というメッセージだけでないアプローチにより結果 的に身体活動を増やすための視点として、座位行動（座りすぎ）に着目した研究をご紹介したい。

座位行動とは、「座位および臥位におけるエネルギー消費量が1.5メッツ以下のすべての覚醒行動」と 定義されている。近年の仕事や生活環境の変化により、世界中の人々の日常生活における座りすぎが 蔓延しており、その健康影響が示されている。これまでの身体活動や運動のガイドラインで推奨され ている中等度以上の身体活動を行うこととは独立して、座位行動の過多は肥満や糖尿病などの危険因 子となっている。また、身体的健康だけではなく、メンタルヘルスにも悪影響を与えること、さらに 就労者においては労働生産性やワーク・エンゲイジメント（健康で生き生きと働く状態）を下げるこ とや、アブセンティズム（体調不良などによりたびたび久勤する状態）やプレゼンティズム（出勤し ているが健康上の問題で仕事に支障をきたし最善の業務ができない状態）などの問題を引き起こして いる。そのため、中等度以上の身体活動量を増やすだけでなく、座位行動を減らすことも重要である。 また、行動科学的視点から考えると、立つこと（座りすぎを減らす）は身体を動かすこと（身体活動 を行う）へのゲートウェイである。つまり、座りっぱなし（座りすぎ）の生活（行動）を学習してしまっ た者を、歩いたり動いたりする行動の頻度を増加させるためには、そのゲートウェイとしての立つこ とからまずは再学習（練習）させるべきであるといえる。そこで本シンポジウムでは、座位行動に着 目した先行研究を概観するとともに、望ましい身体活動へ変容するための方策についてご報告する。 